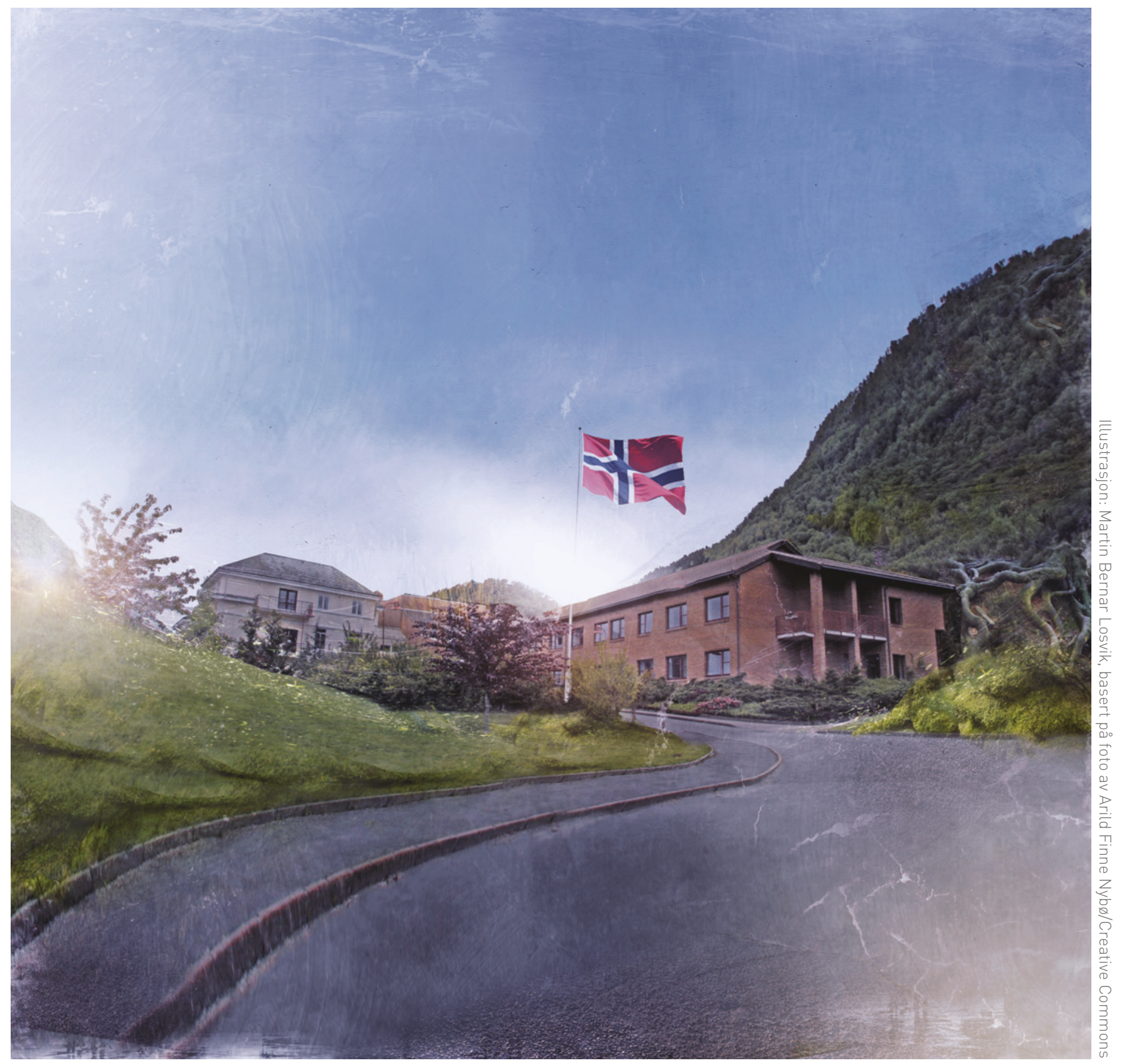

\title{
Eid Legekontor
}

(i)

I Eid kommune i Sogn og Fjordane ligger administrasjonssenteret Nordfjordeid. Tettstedet har 2851 innbyggere, og dersom de har behov for å oppsøke fastlegen sin er det kort vei. Alle Eid kommunes fastleger - åtte i tallet og én turnuslege - holder til på ett legekontor, nemlig Eid Legekontor. 